\title{
The pathways between natural disasters and violence against children: a systematic review
}

\author{
Ilan Cerna-Turoff ${ }^{1 *}$ (D, Hanna-Tina Fischer ${ }^{2}$, Hani Mansourian² and Susannah Mayhew ${ }^{1}$
}

\begin{abstract}
Background: Natural disasters are increasingly affecting a larger segment of the world's population. These highly disruptive events have the potential to produce negative changes in social dynamics and the environment which increase violence against children. We do not currently have a comprehensive understanding of how natural disasters lead to violence against children despite the growing threat to human populations and the importance of violence as a public health issue. The mapping of pathways to violence is critical in designing targeted and evidence-based prevention services for children. We systematically reviewed peer-reviewed articles and grey literature to document the pathways between natural disasters and violence against children and to suggest how this information could be used in the design of future programming.

Methods: We searched 15 bibliographic databases and six grey literature repositories from the earliest date of publication to May 16, 2018. In addition, we solicited grey literature from humanitarian agencies globally that implement child-focused programming after natural disasters. Peer-reviewed articles and grey literature that presented original quantitative or qualitative evidence on how natural disasters led to violence against children were included. The authors synthesized the evidence narratively and used thematic analysis with a constant comparative method to articulate pathways to violence.
\end{abstract}

Results: We identified 6276 unduplicated publications. Nine peer-reviewed articles and 17 grey literature publications met the inclusion criteria. The literature outlined five pathways between natural disasters and violence, including: (i) environmentally induced changes in supervision, accompaniment, and child separation; (ii) transgression of social norms in post-disaster behavior; (iii) economic stress; (iv) negative coping with stress; and (v) insecure shelter and living conditions.

Conclusions: Service providers would benefit from systematic documentation to a high-quality standard of all possible pathways to violence in tailoring programming after natural disasters. The identified pathways in this review provide a foundation for designing targeted prevention services. In addition, the positive coping strategies within certain affected families and communities can be leveraged in implementing strength-based approaches to violence prevention.

Keywords: Children, Violence, Child protection, Natural disaster, Humanitarian crisis, Emergency

\footnotetext{
* Correspondence: it2208@caa.columbia.edu

'Global Health and Development, London School of Hygiene and Tropical

Medicine, London, UK

Full list of author information is available at the end of the article
}

(c) The Author(s). 2021 Open Access This article is licensed under a Creative Commons Attribution 4.0 International License, which permits use, sharing, adaptation, distribution and reproduction in any medium or format, as long as you give appropriate credit to the original author(s) and the source, provide a link to the Creative Commons licence, and indicate if changes were made. The images or other third party material in this article are included in the article's Creative Commons licence, unless indicated otherwise in a credit line to the material. If material is not included in the article's Creative Commons licence and your intended use is not permitted by statutory regulation or exceeds the permitted use, you will need to obtain permission directly from the copyright holder. To view a copy of this licence, visit http://creativecommons.org/licenses/by/4.0/ The Creative Commons Public Domain Dedication waiver (http://creativecommons.org/publicdomain/zero/1.0/) applies to the data made available in this article, unless otherwise stated in a credit line to the data. 


\section{Background}

Natural disasters are increasingly affecting a larger segment of the world's population due to climate change and patterns of human settlement [1]. In 2017, the Centre for Research on the Epidemiology of Disasters (CRED) estimated that natural disasters affected 96 million people, and the United Nations Children's Fund (UNICEF) estimated that natural disasters and other forms of disasters affected approximately 350 million children $[2,3]$. Displacement can be considered an indication of extreme exposure to a disaster event. Between 2008 to 2016, an average of 25.3 million people were displaced by natural disasters each year, and although predictions vary, it is estimated that by 2050 extreme weather events will result in forced displacement of over 200 million people $[4,5]$. The International Displacement Monitoring Centre (IDMC) estimates that natural disasters caused 18.8 million new displacements in 2017, while armed conflict led to 11.8 million new displacements [6].

Children are considered a priority population in humanitarian response because of their vulnerability to experiencing violence after natural disasters [7]. Natural disasters can disrupt services and societal structures, displace populations, and lead to an increased likelihood of trauma, all of which have been associated with violence in past studies [8-12]. Children may be separated from caregivers or orphaned, leaving them with reduced protection from abuse $[13,14]$. In other instances, children may face new vulnerabilities to violence within the home, as their caregivers cope with stressful changes in their environment and threats to their economic stability [15]. Despite a growing number of children affected globally and the implications for public health and development, current understanding is limited as to the full scope of how the social and environmental changes produced by natural disasters may lead to violence against children.

Natural disasters occupy an equivalent status to armed conflict within humanitarian response frameworks and scholarship, and service providers currently implement child protection programming with similar structures, timing, and target populations under a theorical assumption that natural disasters and armed conflict produce identical manifestations of violence against children [1619]. Structural elements and the affected population's interpretation of the events may be distinct, however, and as a result, the pathways to violence against children may differ. One of the few studies that modeled family violence among those affected by the Sri Lankan civil war and the 2004 Indian Ocean Tsunami together found that war exposure predicted violence against children $(\beta$ $=0.34, p<0.001)$, while tsunami exposure acted in the reverse $(\beta=-0.16, p<0.01)$ [20]. During conflict, the presence of armed actors poses a direct risk for violence which often does not exist in the same manner during natural disasters. Communities and individuals, furthermore, can prepare for certain types of natural disasters, such as typhoons or flooding, that reoccur annually. Indigenous coping mechanisms for managing food supplies and providing social support may reduce the negative impact on human populations [21]. While armed conflict may erode a sense of trust in one's community and society, a growing body of psychological and sociological research suggests that natural disasters can improve functioning within families and lead to greater sense of community cohesion and altruism [22-27]. Spatial temporal analysis in Chile, for instance, found that social cohesion on the community level increased after large-scale earthquakes and faded over time as conditions normalized [28]. The differential meanings that affected populations ascribe to natural disasters and armed conflicts seem to influence reactions. As a 2014 psychological study on risk judgement illustrates, when people perceive the cause of something as "natural", they are less likely to judge it as severely as a disaster caused by man [29]. In other words, people respond more negatively to armed conflict than natural disasters, because they perceive natural disasters as outside of human control. This trend is further corroborated in a large-scale review which found that survivors of armed conflict and terrorism had worse mental health outcomes than survivors of natural disasters in samples from 29 countries over two decades [10]. Negative perception and accompanying poor mental health responses may relate to an increased risk of violence against children, as indicated in past studies [30-32]. Greater scholarship on natural disasters and violence against children is needed to begin to decipher potential differences and build child protective services that are specific to natural disasters.

Increasing our understanding of the pathways between natural disasters and violence against children is essential in designing effective violence prevention programs. Service providers have a mandate to provide evidencebased services to prevent any unforeseen harm to children. Identifying the junctures at which one can intervene and the mechanisms by which violence occurs facilitates better tailoring of protection programming. A robust evidence base from stable settings provides helpful insight on factors that can lead to violence against children; however, pathways to violence after natural disasters are less well understood [33, 34]. Elsewhere, we conducted a meta-analysis which showed that there is inconclusive evidence of a direct association between natural disasters and violence against children, but noted that more nuanced research was needed to disentangle pathways to violence [35]. This paper provides a systematic review of peer-reviewed and grey literature to 
deepen the understanding of the pathways between natural disasters and violence against children and to suggest how this information can be used in the design of future programming.

\section{Methods}

This review adhered to the Preferred Reporting Items for Systematic Reviews and Meta-Analyses (PRISMA) guidelines [36].

\section{Search strategy}

We operationalized the definition of children as people under 18 years of age and physical, emotional, and sexual violence by applying definitions utilized in UNICEF's Hidden in Plain Sight report (refer to Table 1) [37]. Violence prevention falls within the field of child protection, which additionally includes broader issues of neglect and exploitation [19]. These aspects of child protection were not included in this review. Natural disasters were defined as environmental hazards without a direct human cause, as per the conventions of disaster response [38]. We recognize, however, that natural disasters may be spurred by human activities or have distal roots in manmade alterations of the physical environment [39]. We included both slow and sudden-onset natural disasters in this review.

We searched 15 bibliographic databases and six grey literature repositories from the earliest date of publication to May 16, 2018 (refer to Additional file 1). All searches were restricted to the English language and included all geographic regions. The search strategy applied terms related to three thematic areas: children, natural disasters, and violence (refer to Additional file 2). The search terms were adapted from vocabulary used in previous systematic reviews of children and physical, emotional, and sexual violence and from the national disaster classification categories listed in the Emergency Events Database [40-42]. Grey literature in the humanitarian field tends to take the form of reports based upon rapid needs assessments, regular monitoring of programmatic activities, and evaluations of gaps in service provision. We included any reports, assessments, or evaluations uploaded to the grey literature repositories in initial searches. We solicited additional grey literature from 12 experts within agencies that lead the global child protection response in humanitarian contexts. Focal points whose area of work includes child protection from UNICEF, United Nations High Commissioner for Refugees (UNHCR), International Organization for Migration (IOM), United Nations Population Fund (UNFPA), and International Federation of Red Cross and Red Crescent Societies (IFRC) were contacted. UNICEF focal points, in turn, solicited recommendations for literature from all Child Protection Coordinators and Information Management Officers (IMOs) worldwide. The Child Protection Area of Responsibility (CP AoR)the global coordination body for child protection in humanitarian contexts led by UNICEF-and IFRC provided supplemental grey literature materials which were not uploaded onto online repositories.

\section{Selection and analysis}

After removal of duplicates, the first and second author independently screened the titles and abstracts of the peer-reviewed articles and the titles and abstracts, executive summaries, and table of contents of the grey literature, as per published guidelines [43]. All peer-reviewed articles and grey literature reports that mentioned both violence against children and natural disasters in these sections were maintained for full text review, after jointly reconciling any conflicting decisions. We used standardized inclusion and exclusion criteria for our decision making in screening (refer to Table 2). A key inclusion criterion was that quantitative, qualitative, or mixed methods sources had to contain original evidence describing information on the pathways between natural disasters and violence against children.

The full text for 16 grey literature reports was not publicly posted, in which case, we attempted to contact the publication authors directly. No author responded to furnish full texts. We independently double extracted topical information on the disaster and violence context and methodological information on the study design and analysis. We did not place any predetermined criteria on pathway structure. We extracted detailed information on how natural disasters led to violence from qualitative

Table 1 Operational definitions of violence

\begin{tabular}{ll}
\hline Violence form & Definition \\
\hline Physical violence & "... all corporal punishment and all other forms of torture, cruel, inhuman or degrading treatment or punishment as well as \\
physical bullying and hazing by adults or by other children" & "Psychological maltreatment, mental abuse, verbal abuse and emotional abuse" \\
$\begin{array}{l}\text { Emotional } \\
\text { violence }\end{array}$ & $\begin{array}{l}\text { "... any sexual activities imposed by an adult on a child against which the child is entitled to protection under criminal law" or } \\
\text { means of pressure" }\end{array}$
\end{tabular}

From: United Nations Children's Fund [37], p. 4 
Table 2 Inclusion and exclusion criteria

\begin{tabular}{|c|c|}
\hline Inclusion criteria & Exclusion criteria \\
\hline $\begin{array}{l}\text { 1. Natural disasters are the exposure of interest } \\
\text { 2. The outcome measure is any form of violence, including physical, emotional, } \\
\text { or sexual violence, bullying, maltreatment, interpersonal violence, or witnessing } \\
\text { domestic violence (DV) } \\
\text { 3. The person who experiences the violence is a child or adolescent under } 18 \\
\text { 4. Original quantitative, qualitative, or mixed methods research identifying } \\
\text { information on the pathway between natural disasters and violence against } \\
\text { children } \\
\text { 5. Peer-reviewed articles or grey literature }\end{array}$ & $\begin{array}{l}\text { 1. Gang violence, female genital mutilation (FGM), neglect, or child } \\
\text { labor, exploitation, trafficking, or marriage as outcomes } \\
\text { 2. Editorials, policy reviews or general reports that do not } \\
\text { introduce new evidence } \\
\text { 3. Conference abstracts } \\
\text { 4. Secondary reviews of literature }\end{array}$ \\
\hline
\end{tabular}

sources. We also extracted the measures between variables in quantitative studies that modeled mediated pathways to violence. If a study used mixed methods, we extracted both qualitative and quantitative information. We solely included information on pathways to violence for those individuals who were below 18 years of age in sources that included acts of violence against adults to abide by our operational definition of children. All information extracted was jointly reconciled by the first and second author. We subsequently conducted a thematic analysis, using a constant comparative method, to sort the data into overarching pathways. The first three authors analyzed themes by jointly discussing how to organize the extracted information from the text into patterns [44]. Using a constant comparative method, the emergent themes were iteratively revised until reaching a consensus that the pathways captured the full meaning of the contained information [45]. The authors' positionality as insiders in the humanitarian child protection field aided in understanding the lines of demarcation between pathways and supported informed debates on the appropriate organization of information.

\section{Quality appraisal}

We used the Critical Appraisal Skills Programme's Qualitative Research Checklist and the National Institute of Health Quality Assessment Tools for Cohort and Cross-sectional and Case-Control Study Designs as means of critical comparison (refer to Additional file 3) $[46,47]$. In the case of mixed-methods studies, we evaluated the qualitative and quantitative components separately. We positively scored the appropriateness of the article or report's methodology if it matched at least one of its outlined aims and objectives. The final question in the Critical Appraisal checklist is a subjective determination of value. We rated value based on the article or report's provision of nuanced information and practical recommendations for stakeholders. The research team used these tools in comparing quality, rather than in inclusion and exclusion decisions, which is in-line with the Cochrane Handbook's guidance for systematic reviews [48].

\section{Results}

\section{Characteristics of peer-reviewed articles and grey literature}

We identified a total of 1045 unique peer-reviewed articles and 5231 grey literature publications (refer to Fig. 1). Nine peer-reviewed articles and 17 grey literature publications matched the criteria for inclusion. Amongst the peer-reviewed articles, five of the nine studies utilized qualitative methods, three applied quantitative methods, and one study used both qualitative and quantitative methods. All grey literature used qualitative methodologies.

Two of the peer-reviewed articles described flooding events in 1998 and 2007 in Bangladesh [15, 49], and three publications described four separate disasters in the United States [50-52]. The remaining articles described natural disasters in Haiti, Nepal, and Sri Lankatwo focused on devastating earthquakes [53, 54], and two examined the 2004 Indian Ocean Tsunami [20, 55]. The grey literature described disasters in a range of regions, with the greatest number occurring in Asia and the Pacific and a single report from the Americas on the aftermath of the 2010 Haitian earthquake [56-67]. Drought and extreme tropical storms in the form of typhoons, cyclones, or hurricanes were the most common disasters in the grey literature [56-61, 66, 68-72]. A single report incorporated a temporal element in explaining the pathways to violence; in the Lao People's Democratic Republic, commonly known as "Laos", adolescent and adult respondents mentioned that the lack of safety and surveillance and economic hardship in the first one to two weeks after the disaster led to spikes in violence against children that returned to normal levels afterwards [57]. An interview with a Child Protective Services worker as part of a mixed methods study indicated that a possible reverse pattern existed in the United States. He hypothesized that frustration grew over time due to the slow pace of recovery and led to increases in violence against children. The amount of time was not specified, however [50]. Two of the five countries in the peer-reviewed articles and three of the 13 countries in the grey literature were concurrently experiencing armed conflict or some other form of man-made disaster [73]. 


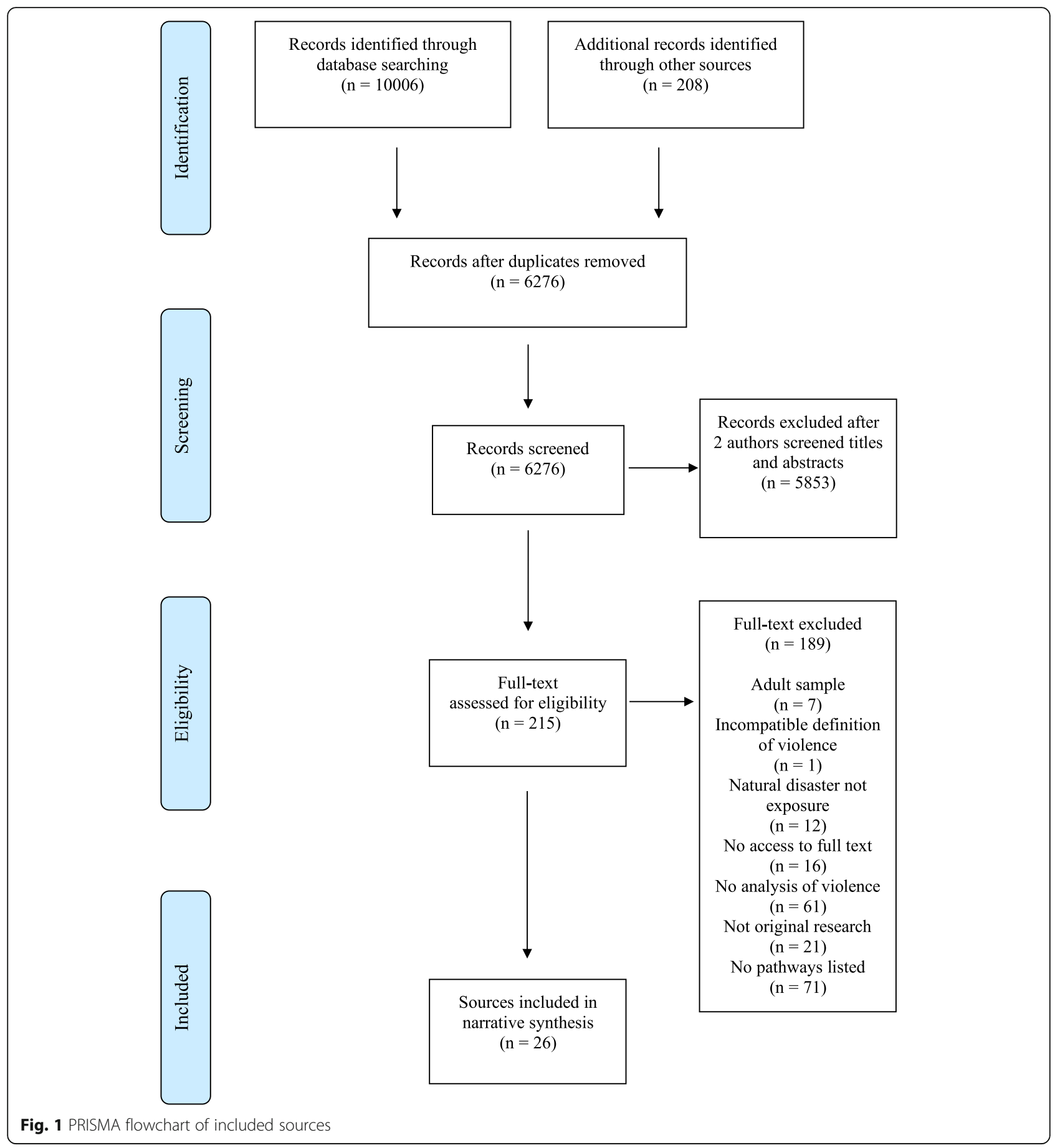

Sexual violence was the most commonly documented form of violence in the peer-reviewed articles barring Biswas et al. [15], which described physical and emotional violence committed by mothers and fathers against children, and Terranova et al. [51] and Scott et al. [52], which described physical and emotional bullying behaviors among children. In the grey literature, all but three publications contained information on pathways to sexual violence [58, 61, 65]. Physical violence was the second most common form of violence [56, 58 , 61, 62, 66-68, 72]. Emotional violence and all forms of bullying were underrepresented in the grey literature $[64,65,69]$. The peer-reviewed literature mainly collected information on children below the age of 18. One article did not specify the exact age range among children under 18 [55], and another recruited respondents as old as 19 years [49]. The grey literature often did not specify the age range of children or used variable age 
ranges, with some individuals as old as 20 categorized as children [56-58, 61, 66, 68, 69, 71, 72].

\section{Quality of evidence gathering, analysis, and reporting practices}

The peer-reviewed articles and grey literature publications exhibited variable levels of quality in their evidence gathering and reporting practices (refer to Table 3). Six peer-reviewed articles used qualitative methods, namely semi-structured interviews with affected individuals and key informants [15, 49, 50, 53-55]. Four peer-reviewed articles relied upon quantitative surveys that sampled households or school-going children and their parents to collect information on pathways $[15,20,51,52]$. Overall, the included peer-reviewed articles appropriately analyzed the data. One article, however, attempted to infer quantitative information on incidence from qualitative interviews [55], and another used structural equation modeling which is sensitive to choices in how one analyzes data and relies upon numerous assumptions in its parameters $[52,74]$. Within the body of qualitative peerreviewed publications, several unclearly reported on their data collection methods and did not distinguish between the authors' views and those of the respondents. Quotes in some instances were extracted without any description of how the information was generated [15], and on the other extreme, information was presented without directly citing respondents in a clear manner [53, 55]. In contrast, Rashid and Michaud's [49] study of adolescent girls was an example of a nuanced description of violence-related issues after floods in Bangladesh. The study provided explicit analysis of positionality, as Rashid discussed her insider-outsider status as a Bangladeshi who was raised abroad and Michaud's Canadian identity. Amongst the quantitative peer-reviewed publications, a major threat of bias came from sampling choices. Several studies used samples that were not representative of the entire affected population of children but interpreted them as such. School-going children formed a key group of respondents, but the pathways to violence among those that have access to education may differ from those that do not attend school [20, 51, 52].

The grey literature applied a combination of qualitative methodologies, including interviews with directly affected communities, focus group discussions (FGD), direct observation, and key informant interviews. All studies appropriately sought out both female and male respondents to capture gendered perspectives of pathways and separated FGD by gender. Notably, most of the grey literature directly engaged children as respondents, and two reports partitioned children into separate age ranges [64, 68]. The chosen methodologies, however, were not described in detail, and reporting was minimal at best. The grey literature treated the evidence as if it was representative of the entire affected population and did not explore limitations or differences in perspectives. Some reports did not include an abstract or overview, while others did not provide complete information on the research questions, methodologies, and findings. Within the main body of text, only one report provided details on how the authors synthesized evidence [64]. The presentation of the findings on pathways was similarly presented without sufficient depth. It was often impossible to ascertain the extent to which the description of the pathway constituted the opinion of the respondents or a secondary interpretation by the publication authors. The extent to which local researchers led the production of knowledge, likewise, was challenging to assess. Four publications indicated that they were written or led by international researchers from outside of the disaster country $[57,59,62,63]$; two others implied that international teams had a significant role in the production of knowledge [56, 60]; and seven additional publications were spearheaded by the national arm of an international non-governmental organization [64-66, 68, 69, 71, 72]. A governmental agency was the first author for three reports from Tonga, Zimbabwe, and Bangladesh [61, 67, 70].

\section{Pathways between natural disasters and violence against children}

The pathways identified in the literature were thematically organized into five categories: (i) environmentally induced changes in supervision, accompaniment, and child separation; (ii) transgression of social norms in postdisaster behavior; (iii) economic stress; (iv) negative coping with stress; and (v) insecure shelter and living conditions.

\section{Environmentally induced changes in supervision, accompaniment, and child separation}

Respondents identified changes following natural disasters in caregiver and children's travel and movement which produced new patterns of accompaniment and separation. In some settings, the changes increased violence, and in others, they were protective. In Ethiopia, for instance, two grey literature reports identified new gendered patterns of movement that increased sexual violence risk. During the drought, girls ventured further away from their homes to find water or were left in their households alone for long time periods while their mothers fetched water. As water sources became scarcer, girls began to collect water at night to avoid queues during the day. Male family members, likewise, were forced to migrate longer distances to find paid work and tend to their cattle, which left female members of the household alone [69, 71]. Each of these changes-movement to isolated locations, being left unaccompanied in the 


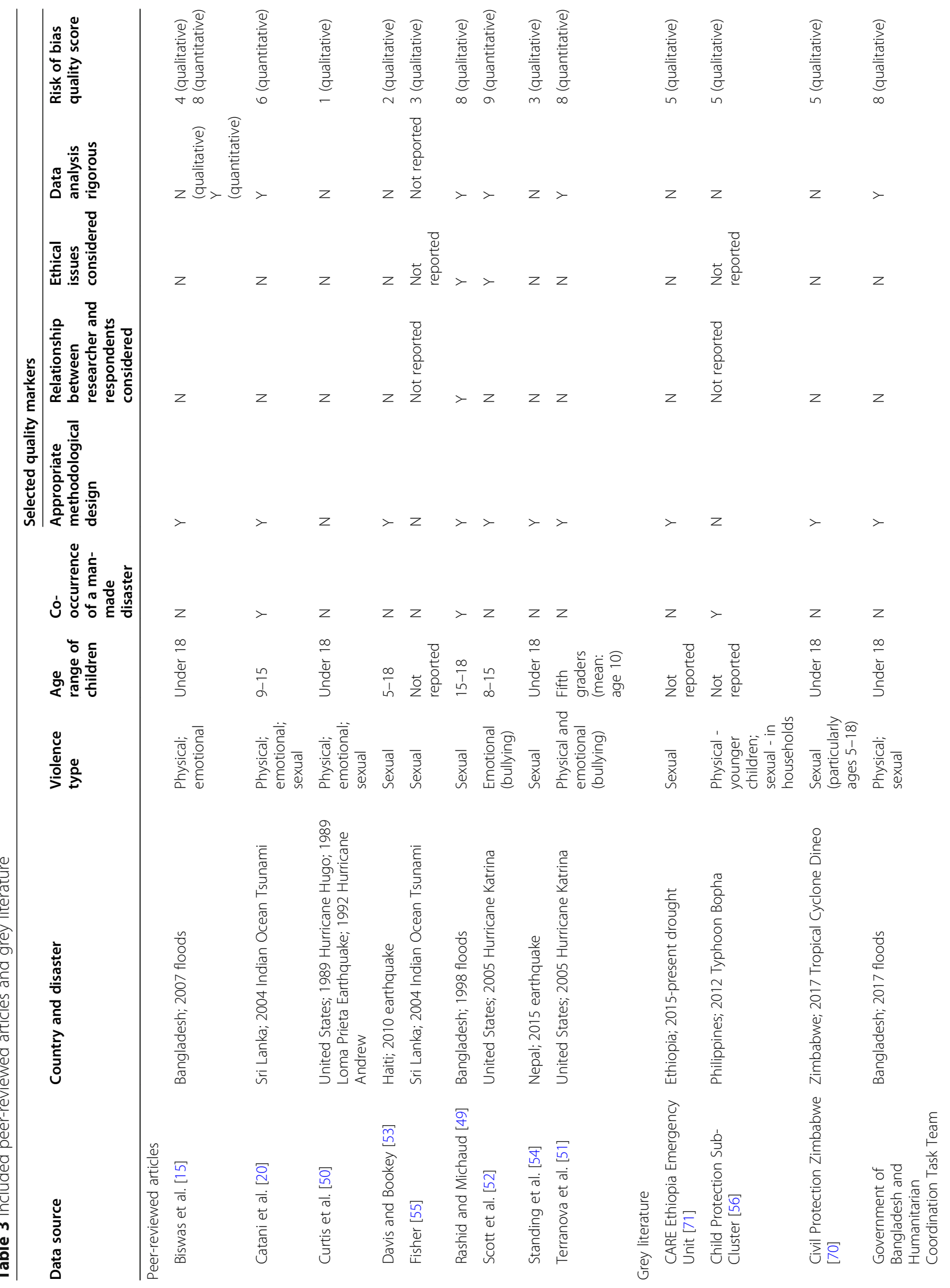




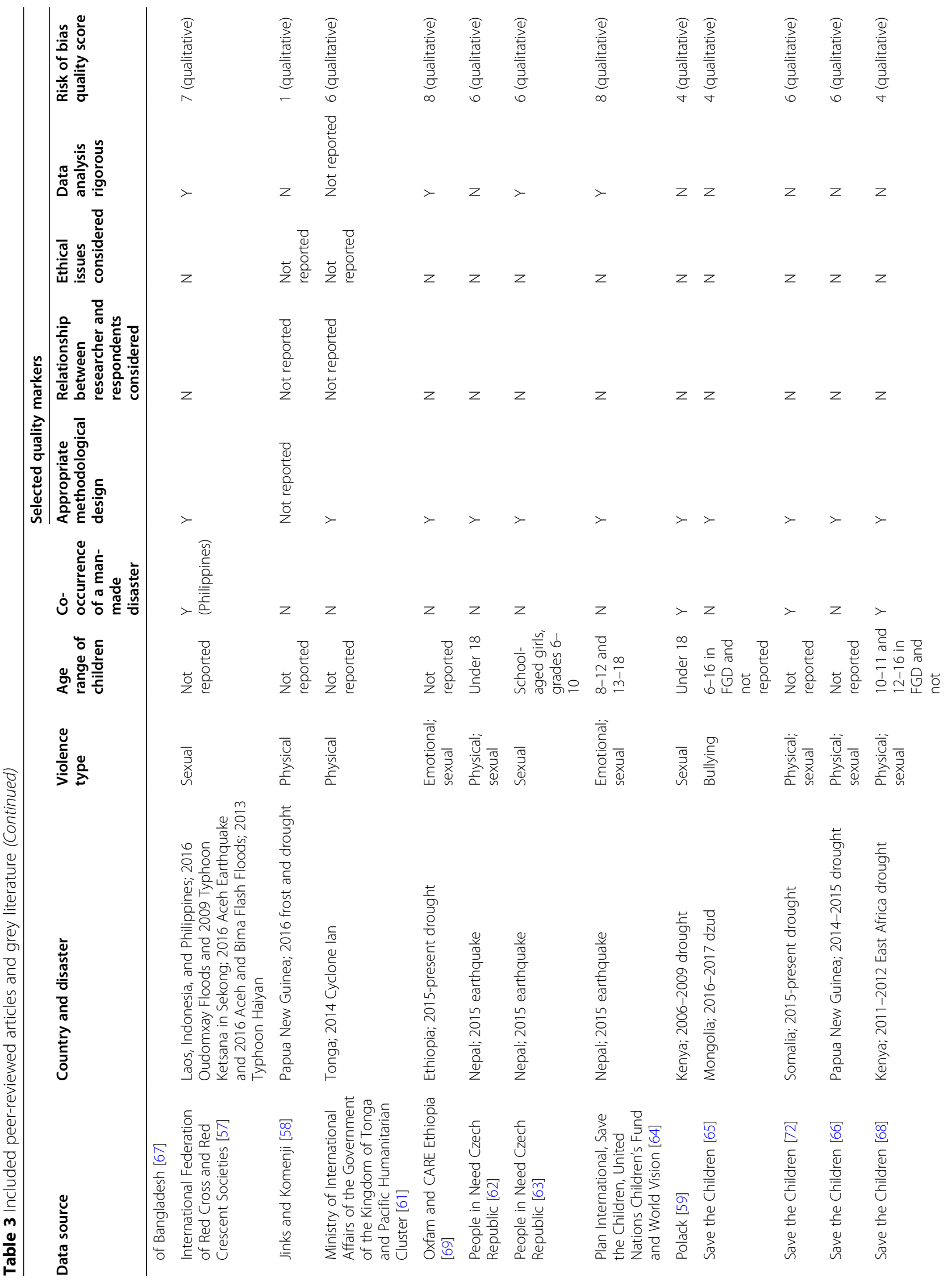




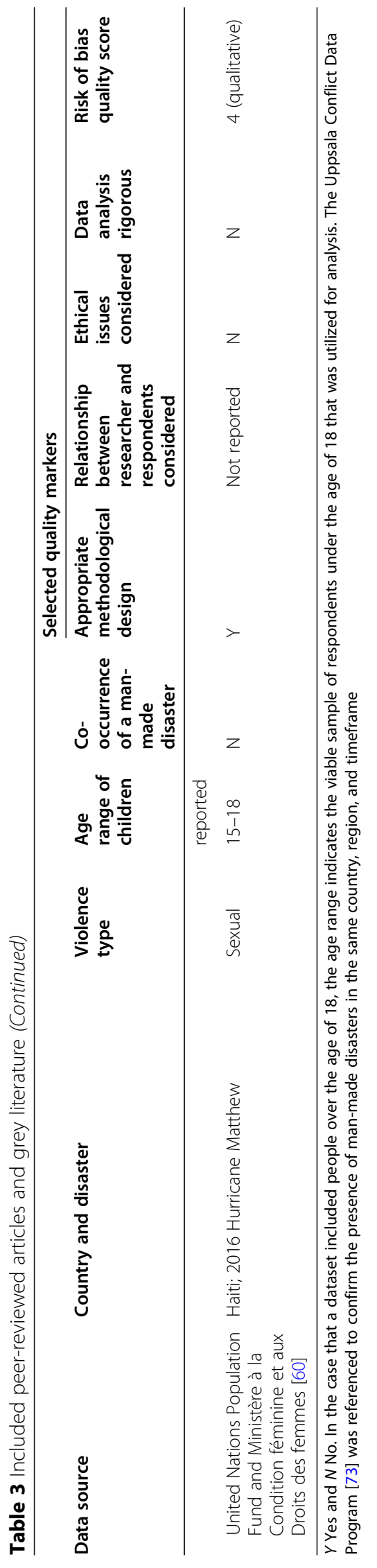


home, and travel in darkness-increased the risk of violence against girls. Findings from droughts in Kenya and Somalia similarly reinforced that girls were at risk of sexual violence when they searched for food, firewood, and water or travelled for work, particularly in the early morning or evening [59, 72]. Street harassment was common, and although respondents admitted that it had existed prior, "It was more scary during the floods because there were more mastaans [hoodlums] and goondahs [thugs] hanging about" (Rashid and Michaud [49], p. 62). This increase in unknown men congregating in a new shared space created a situation ripe for opportunistic sexual violence. Women and girls increasingly relied on physical proximity to their former neighbors and communities or on sending girls to stay with distant family members as a means of protection. In contrast, boys experienced distinct forms of violence as they travelled. Respondents believed that boys who moved to towns and away from their homes in Somalia during a drought faced heightened risk of physical violence from employers and other adults [72]. Violence between children additionally increased in some settings. In Mongolia, adults from herder communities spent a greater amount of time tending to cattle during extreme winter conditions, which led to minimal supervision and increases in bullying from peers [65].

Permanent separation from friends and adult caregivers produced some of the greatest ongoing sexual violence risks, especially for girls. Girls who lived alone in camps after the 2010 Haitian earthquake and after the 2015 Nepal earthquake faced sexual violence from strangers, as spaces were often transitory and lacked strong systems of policing and social control [53, 54]. Respondents in one study believed that girls whose mothers died during the 2004 Indian Ocean Tsunami in Sri Lanka were at risk of sexual violence within their homes from fathers, brothers, or other male family members. Risk was attributed to the isolation of girls with male family members and the reduced ability of adult members of the household to have sexual intercourse, given the lack of privacy [55]. The provided reasons are proximal, however, and do not analyze problematic aspects of gender norms which dictate that spaces must be gender segregated to prevent sexual violence and that men and boys cannot control sexual desires, notwithstanding the societal taboo of incest.

In contrast, a series of grey literature reports described how changes in travel and movement protected children from violence. After the 2015 Nepal earthquake, respondents mentioned that parents became more protective of their children and restricted their mobility, leading to less violence from strangers [64]. The reason why a shift occurred in parenting and how it intersected with parents' past disaster experiences was not explored. In a report on a Kenyan drought, some respondents believed that sexual violence against girls decreased, because girls who would have faced risks while herding were now either in school or working as domestic helpers since the cattle had largely died [68]. Two grey literature reports from the Pacific region highlighted culturally-specific coping mechanisms that prevented violence after natural disasters $[61,66]$. Although not dissected further, communities in Tonga outlined that traditional values led to the creation of community safety nets after a cyclone so that adults in the communities watched children outside of their homes and prevented any acts of violence [61]. Respondents in Papua New Guinea similarly mentioned that joint family structures were protective against sexual violence during a drought, because young children were not left alone, and children travelled long distances in groups to fetch water [66].

\section{Transgression of social norms in post-disaster behavior} Natural disasters lead to structural changes, and individuals may adapt their behaviors in ways that transgress social norms. A clash of meaning exists when individuals interpret behavior by what is deemed "normal" in stable settings. This signification of behaviors as transgressive may cause individuals to act out in violent ways against children. In Nepal, it is traditionally believed that women and girls are "unclean" when they menstruate, but girls had limited access to basic feminine hygiene products after displacement from flooding. They commonly slept outside of their tents to avoid "polluting" the household and as a result, experienced sexual violence from strangers [54]. Similarly, in Bangladesh after floods, adolescent girls mentioned that they faced sexual harassment en route to work, because by wading through flood waters, it caused the fabric of their saris to cling to their bodies in a socially unacceptable manner [49]. In the Afar region of Ethiopia, some communities practice a tradition known as mira, or entitlement for men to have forced sex with women and girls while their husbands are away. Mira increased the rape of married women and girls as male members of the household migrated further and for longer periods of time to find work during a drought [71]. Another example from Somalia involves increases in physical violence against boys. Harmful gender norms dictate that boys are expected to generate income for the family. If boys failed to support their families, caregivers considered physical violence as merited despite the constriction of economic opportunities during a drought [72]. These acts of violence occurred after natural disasters, but normative beliefs and attitudes about physical violence often preceded the disaster event, as underscored in focus groups of men and women in Bangladesh following the 2017 floods [67]. 


\section{Economic stress}

The economic stress of natural disasters especially affects households living in poverty $[15,57,62]$. One proposed reason is that men, frustrated by economic loss and hardship, misdirect their anger at sexual partners and children. Men identified insufficient cash assistance after the 2015 Nepal earthquake and economic loss from not harvesting crops before floods in Laos as reasons for why they were physically violent $[57,62]$. After flooding in Bangladesh, men who received aid or took out personal loans were more than twice as likely to be physically or emotionally violent with their children than those who could rely on personal savings (adjusted odds ratio [aOR]: 2.06, 95\% CI: 1.08-3.95, $p<0.01$ and aOR: 2.62, 95\% CI: $1.45-4.74, p<0.001$, respectively) [15]. Financial instability, loss of income generating activities, and economic reliance on others seemed to elicit a similar violent reaction among men. The deeper structural drivers relate to gender norms that dictate that men are supposed to be economic providers and are entitled to act out their emotions on women and children. However, the trigger for the behavior was inextricably linked to economic stress and loss caused by natural disasters.

Women were likewise affected by economic stress. In Sri Lanka after the 2004 Indian Ocean Tsunami, decreases in economic status predicted violence from both mothers and fathers $(\beta=-0.20, p<0.001)$ [20]. Mothers in Bangladesh were the member of the household that was most often physically violent against children, and those who did not generate an income outside of their households were 3.53 times (95\% CI: 1.67-7.46) more likely to abuse their children emotionally or physically [15]. An interview with a father from the study describes why caregivers were physically abusive after economic loss, "My child asked me in the morning to bring back cookies when I went outside to search for work. It was happening sometimes when we could only afford to eat once a day, so how could I buy cookies? I couldn't control myself and I slapped the child" (Biswas et al. [15], p. 6). Children could not understand the financial strain on their households, and in demanding superfluous goods, it triggered caregivers to lash out in frustration and guilt. In addition, children were occasionally physically violent against each other due to economic stress. After Typhoon Bopha in the Philippines, a minority of older children were physically abusive against their younger siblings as a result of competition for limited food and the stress of confined living quarters [56]. Girls, in particular, face physical and sexual violence risk outside of their homes. Economic hardship pushes women and girls into precarious employment where work relationships are often exploitative. Two reports specifically mentioned that employers took advantage of the increased vulnerability and power imbalances to abuse their underage female employees physically and sexually $[57,68]$.

\section{Negative coping with stress}

The literature documents two ways by which negative coping after natural disasters leads to violence against children. First, a proportion of men respond to natural disasters by abusing substances and gambling, which exacerbates sexual and physical violence [54, 62, 63]. Evidence from a study in Sri Lanka post-tsunami indicated that fathers' alcohol use was a significant factor associated with committing physical, emotional, or sexual abuse against their children $(\beta=0.16, p<0.01)$ [20]. Similarly, after the 2015 earthquake in Nepal, men negatively coped with stress by purchasing and consuming greater amounts of alcohol despite a three-fold increase in price. Alcohol abuse emboldened men to commit acts of sexual violence against girls in the community [62]. Violence against women by their partners may have further ripple effects on children. For instance, women in Bangladesh after floods who experienced physical, emotional, or sexual violence from their husbands were nearly five times more likely to abuse their children than those who were not (aOR: 4.53, 95\% CI: 1.94-10.60) [15].

Second, caregivers reported that they had less patience for children during a drought in Ethiopia and after flooding in Bangladesh and as a result, would more frequently and disproportionately chastise their children when asked questions [15, 71]. The phenomenon is poignantly captured in the words of a respondent, "I can't stop my emotions during a devasting situation. My 6 years old child always wants to know about this and about that and it disturbs me. So I say something bad to my child ..." (Biswas et al. [15], p. 6). Caregivers' capacity to regulate their anger was eroded by the stress of the disaster, and they misplaced their anger on their children. The inability of adults to regulate their anger also affects children outside of their immediate households. In Papua New Guinea, hungry children who stole vegetables from neighboring plots were repeatedly beaten [58].

An extreme stress reaction to natural disasters can manifest as post-traumatic stress disorder (PTSD) for a minority of the population $[75,76]$. The literature identified in this review, however, yielded inconclusive evidence on the pathway between natural disaster exposure, PTSD, and violence. Using structural equation modeling, Scott et al. [52] found that the relationship between exposure to Hurricane Katrina in the United States and emotional bullying was completely mediated by PTSD. The finding contrasted with hierarchical modeling which revealed that PTSD did not predict emotional or physical bullying after Hurricane Katrina [51]. 


\section{Insecure shelter and living conditions}

The safety of shelter and living conditions directly relates to a risk of sexual violence against children after natural disasters [77]. Respondents mentioned several elements of inadequate shelter construction and logistical management that increased risk, including: the ease of entry when flimsy tarp materials were used for temporary housing or the inability to lock housing structures; a lack of privacy due to the design or incomplete construction of shelters which allowed men to see girls while changing clothing; and most commonly, the overcrowding of unknown families into the same living space [53, 54, 57, 60, 63, 64, 70]. Rashid and Michaud's [49] study of the effects of flooding on adolescent girls in Bangladesh described shelter risks that were particular to floods. Adolescent girls were forced to sleep on rooftops due to the submersion of the lower levels of their homes. Sleeping outside produced vulnerability to sexual violence from strangers at night. Girls, furthermore, were increasingly exposed to unknown men while conducting their daily activities outside of the household, such as bathing and using latrines. As was the case with housing, the structure of the bathing and toilet facilities may increase the risk of sexual violence. The spaces and structures had a general inadequacy of lighting and were not gender segregated or securely locked $[49,53,57,62]$. One report nuances the discussion by stating that although structural insecurity existed in communities prior to natural disasters, the events exacerbated safety risk by limiting the mobility of women and girls [67].

\section{Discussion}

We identified multiple pathways between natural disasters and violence against children. Each pathway presents a meaningful juncture to intervene in preventing violence. It is promising that many interventions already exist that can be implemented or adapted, and the expertise and operational structure do not need to be built anew; for example: SASA! for norms change [78], Parents Make the Difference for positive parenting [79], and Cure Violence for creating safe environments [80], to name a few. In addition, global guidance, as outlined in the Minimum Standards for Child Protection in $\mathrm{Hu}$ manitarian Action (CPMS) and the World Health Organization's (WHO) INSPIRE: Seven Strategies for Ending Violence against Children, provide standards that should be met in building key components of interventions [19, 81]. Service providers would benefit from linking programmatic activities to pathway structures and ensuring robust coordination across agencies to address all possible paths to violence. As an example, cash transfers for families via male caregivers may alleviate economic stress but may also increase violence against children without changing gender norms that stigmatize men for not being able to provide for their families economically. Another concurrent pathway may lead to violence by way of negative coping with stress. Interventions to prevent violence against children in this instance would therefore need to be multi-pronged and change community norms, provide psychosocial support, and reduce problematic substance use to be effective. Alternative provision of cash transfers to female caregivers would still likely lead to violence against children without intervening on normative gender roles with their male partners and providing psychosocial support and parenting interventions for women. Overall, identification of the underlying pathways to violence against children aids in making decisions about programmatic structure more intentional and targeted.

Economic stress and negative coping with stress were identified as two important pathways to violence against children in this review. It is unclear if investment should be equal across all pathways, however, and further research should compare the relative importance of these pathways across natural disaster contexts. It is likely that many pathways are still unknown and should be identified to improve the effectiveness of programmatic design. Pathways to violence may likewise differ by violence type. The majority of studies captured information on sexual violence which is unexpected, given that physical and emotional violence against children are often more prominent measures in the field of child protection [82]. Comprehensive mapping is needed to decipher how pathways may differ for each specific form of violence. Furthermore, this review indicated that pathways between natural disasters and violence against children are indirect. An analysis of the effect of natural disasters on violence, therefore, may mask the underlying relationship without taking mediating factors into account [35, 83]. Future evidence production would benefit from measuring co-occurring factors and accounting for the timing of each element on the pathway between a natural disaster event and violence against children.

Nuanced information on pathways is key in understanding how natural disasters lead to violence against children. The evidence base needs greater documentation of how violence differs across settings, by natural disasters type, and in instances where concurrent manmade disasters exist [35]. These differences likely have major implications for violence outcomes. Larger questions remain about whether armed conflict and natural disasters share all pathways to violence. This review did not identify radically different mechanisms. The single study from Sri Lanka that directly compared exposure types, however, found that natural disasters reduced levels of physical and emotional violence in households, whereas armed conflict increased these forms of violence 
[20]. Several grey literature sources in this review further highlighted that families and communities exhibited protective behaviors after natural disasters which respondents attributed to reductions in violence $[61,64,66$, 68]. Although tentative, the evidence suggests that violence against children may not always increase after natural disasters; that armed conflict and natural disasters may act differently to produce different violence patterns; and that certain positive coping behaviors may successfully moderate or prevent violence after natural disasters [50]. Greater research is needed, therefore, to identify why differences may exist and which factors support the development of protective behaviors. Moreover, given the overarching evidence in this review that multiple pathways to violence exist after a natural disaster event, a better understanding of attributes and behaviors that prevent violence is paramount. In particular, the current body of academic research could benefit from a more comprehensive approach in documenting which indigenous strategies have been successfully implemented after natural disasters. Academic research should capture information on individual strengths and protective behaviors, rather than solely factors that increase vulnerabilities to violence. Furthermore, pathways to violence may differ between developed and developing countries. A 20-year study of mental health after natural disasters found that people in developing countries faired far worse than those in developed countries. The authors' suggested that individuals have negative mental health outcomes when they knew that they could not access social services [10]. The implication is that individuals living in developing countries are potentially at greater risk of committing violence against children after natural disasters, given worse mental health indicators on the individual level, but also, are at higher risk because social safety nets and systems of protection are often not robust [84].

The impact of natural disasters is likely uneven across populations. Gender is an important axis of difference which was not thoroughly explored in the peer-reviewed articles and grey literature. Girls and boys experience sexual violence at different levels in stable settings, and this dynamic may be reflected in natural disasters [85]. Past research has found that people with lower education and minority populations receive less social support in disaster recovery, which impacts the ability to cope with an overwhelming situation [86]. Although not a direct measurement, a recent longitudinal study from the United States confirmed that particularly African Americans and Hispanics, individuals with lower levels of education, and those who did not own homes were less likely to recover economically from natural disasters, and in fact, natural disasters entrenched wealth inequalities further [87]. Considering the clustering and intersectionality of poverty, limited educational opportunities, and race and ethnicity, it is probable that natural disasters compound already existent vulnerabilities in specific groups [88, 89].

Our understanding of pathways between natural disasters and violence against children hinges upon the quality of humanitarian evidence gathering and reporting. Much of the information in this review, particularly within the qualitative studies and grey literature, did not present information in a standardized or comprehensive manner, which hinders cross comparison and meaningful interpretation. Greater documentation of methods is needed to enable the reader to understand how the data was collected and assess the accuracy of the author's description of pathways. In both qualitative and quantitative studies, the study population should correspond with the research question. The literature base would benefit from interrogating which segment of the overall population of children is represented in each study and its appropriateness; how these choices lead to identification of different pathways to violence; and which biases exist in reporting information, given the positionality and identity of data collectors in relation to the affected population and the authors' approach in synthesizing information.

Despite the limitations of the existing literature, it is possible to draw a tentative mapping of the likely pathways to violence and possible points of intervention that service providers should consider when designing their programming. The mapping outlined presents a starting point in identifying viable points for intervention and creating programmatic structures to prevent violence against children (refer to Fig. 2).

\section{Strengths and limitations}

We presented a detailed examination of peer-reviewed articles and grey literature on the pathways between natural disasters and violence against children. We extensively reviewed grey literature, which is often neglected in systematic reviews but is the main body of evidence in the humanitarian field. We included all forms of natural disasters globally, particularly in low- and middleincome countries. Our review, thus, contributes to a better understanding of the research gaps and programmatic opportunities for protecting children from violence in the wake of natural disasters. The review was limited by inconsistent posting of grey literature in online repositories. We examined the prominent grey literature sites for child protection in humanitarian settings, supplementing our search with targeted outreach to key international bodies that lead response efforts. However, we likely excluded sources that were not posted on online clearing houses or were not available in electronic form. Grey literature reports frequently are 


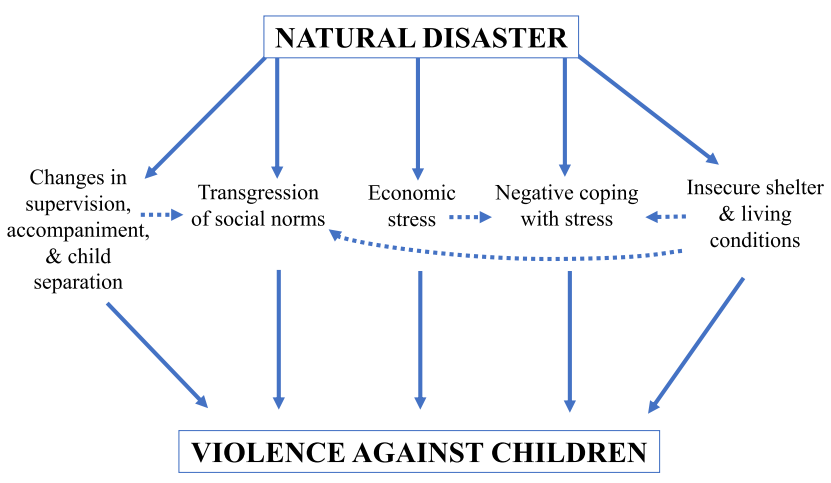

\begin{tabular}{|c|c|c|c|c|}
\hline $\begin{array}{l}\text { Changes in } \\
\text { supervision, } \\
\text { accompaniment, \& } \\
\text { child separation }\end{array}$ & $\begin{array}{l}\text { Transgression of } \\
\text { social norms }\end{array}$ & Economic stress & $\begin{array}{l}\text { Negative coping } \\
\text { with stress }\end{array}$ & $\begin{array}{l}\text { Insecure shelter \& } \\
\text { living conditions }\end{array}$ \\
\hline $\begin{array}{l}\text { Community } \\
\text { sensitization \& risk } \\
\text { reduction training } \\
\text { (i.e. importance of } \\
\text { mixed-gender water } \\
\text { \& firewood } \\
\text { collection) }\end{array}$ & $\begin{array}{l}\text { Menstrual hygiene } \\
\text { management kit } \\
\text { distribution for } \\
\text { violence prevention }\end{array}$ & $\begin{array}{l}\text { Cash transfer \& } \\
\text { livelihoods } \\
\text { programming }\end{array}$ & Psychosocial support & $\begin{array}{l}\text { Shelter engagement } \\
\text { on policies for the } \\
\text { number \& } \\
\text { composition of } \\
\text { temporary housing } \\
\text { units }\end{array}$ \\
\hline $\begin{array}{l}\text { Risk mapping \& } \\
\text { adaptation of } \\
\text { security planning }\end{array}$ & $\begin{array}{l}\text { Shelter \& WASH } \\
\text { engagement on } \\
\text { gender-segregated } \\
\text { sleeping \& bathing } \\
\text { in temporary } \\
\text { housing }\end{array}$ & $\begin{array}{l}\text { Gender-sensitive, } \\
\text { psychosocial support } \\
\text { to adult male } \\
\text { caregivers }\end{array}$ & $\begin{array}{l}\text { Substance abuse } \\
\text { counselling }\end{array}$ & $\begin{array}{l}\text { Shelter \& WASH } \\
\text { engagement on } \\
\text { gender-segregated } \\
\text { sleeping \& bathing } \\
\text { in temporary } \\
\text { housing }\end{array}$ \\
\hline $\begin{array}{l}\text { Local income } \\
\text { generation } \\
\text { programming, } \\
\text { tailored to boys \& } \\
\text { girls }\end{array}$ & $\begin{array}{l}\text { Training of men } \& \\
\text { boys to prevent } \\
\text { sexual violence }\end{array}$ & $\begin{array}{c}\text { Trauma-informed } \\
\text { parenting } \\
\text { interventions }\end{array}$ & $\begin{array}{l}\text { Integrated } \\
\text { prevention } \\
\text { programming for } \\
\text { intimate partner } \\
\text { violence \& violence } \\
\text { against children }\end{array}$ & $\begin{array}{l}\text { Shelter engagement } \\
\text { in secure } \\
\text { construction \& } \\
\text { locking of temporary } \\
\text { housing }\end{array}$ \\
\hline $\begin{array}{l}\text { Incorporation of } \\
\text { family \& community } \\
\text { safety nets into } \\
\text { programming }\end{array}$ & $\begin{array}{l}\text { Age- \& gender- } \\
\text { sensitive income } \\
\text { generation } \\
\text { programming }\end{array}$ & $\begin{array}{l}\text { Policy \& response } \\
\text { strengthening for } \\
\text { sexual violence in } \\
\text { work settings }\end{array}$ & $\begin{array}{l}\text { School-based } \\
\text { bullying policy \& } \\
\text { education }\end{array}$ & $\begin{array}{l}\text { Shelter \& WASH } \\
\text { engagement on } \\
\text { lighting in public } \\
\text { spaces \& latrines }\end{array}$ \\
\hline
\end{tabular}

Fig. 2 Pathways to violence against children and potential interventions by pathway type. WASH refers to the Water, Sanitation, and Hygiene sector and programming of a humanitarian response

not shared publicly and so, would not have been identified. As an English language review, we may have missed a subgroup of articles and reports written in non-English languages.

\section{Implications for improving future practice}

Child-focused programming after natural disasters is often designed to address isolated pathways to violence against children. Our findings illustrate the need to design programming that responds to multiple pathways. Protection interventions that address a single pathway to violence are likely to prove ineffective, because other routes to violence against children continue to exist. A comprehensive mapping of all potential pathways to violence against children after natural disasters would allow for individual agencies to better tailor their programmatic design to key upstream drivers of violence and for coordination bodies to identify any gaps in response efforts. Isolated peer-reviewed articles and grey literature publications importantly identified cultural and location-specific coping strategies that were protective. Families and communities may possess indigenous knowledge that reduces the negative impact of natural disasters and aids in protecting children from violence $[61,66]$. As a result, natural disasters may offer opportunities to structure child protection interventions to support and bolster local response efforts. The approach has implications in terms of effectiveness (i.e., building upon existent prevention strategies is easier than promoting strategies seen as externally enforced or outside of societal norms), financing, and paradigm shifts to localize response after natural disasters in line with global commitments, such as the Grand Bargain for humanitarian financing [90]. This review, likewise, highlights our need for greater documentation, given the paucity of sources, and higher quality information for future investigation and intervention. 


\section{Conclusions}

As natural disasters increasingly affect human populations, service providers need to better understand the pathways between natural disasters and violence against children. The pathways identified in this systematic review highlight specific elements of the post-disaster environment that can be leveraged or targeted to create effective interventions. Comprehensive mapping of pathways ensures effective coverage of programming to counter all possible paths to violence. By improving the systematic collection of information to a high standard, we can build more appropriate and targeted interventions to prevent violence against children.

\section{Abbreviations \\ aOR: Adjusted Odds Ratio; Cl: Confidence Interval; CP AoR: Child Protection Area of Responsibility; CPMS: Minimum Standards for Child Protection in Humanitarian Action; CRED: Centre for Research on the Epidemiology of Disasters; DV: Domestic violence; FGD: Focus group discussions; FGM: Female genital mutilation; IDMC: International Displacement Monitoring Centre; IFRC: International Federation of Red Cross and Red Crescent Societies; IOM: International Organization for Migration; IMO: Information Management Officer; PRISMA: Preferred Reporting Items for Systematic Reviews and Meta- Analyses; PTSD: Post-traumatic stress disorder; UNFPA: United Nations Population Fund; UNHCR: United Nations High Commissioner for Refugees; UNICEF: United Nations Children's Fund; WASH: Water, Sanitation, and Hygiene; WHO: World Health Organization}

\section{Supplementary Information}

The online version contains supplementary material available at https://doi. org/10.1186/s12889-021-11252-3.

Additional file 1. List of literature repositories searched.

Additional file 2. Search strategy in Medline/PubMED.

Additional file $\mathbf{3}$. Risk of bias rating for included peer-reviewed articles and grey literature.

\section{Acknowledgements}

We would like to especially thank all of our colleagues at UNICEF, UNHCR, IOM, UNFPA, and IFRC for their participation and literature recommendations. In particular, we would like to thank the CP AoR for their support in providing sources and connections to humanitarian actors in the field. We would also like to extend our thanks to Dr. Karen Devries for advising on literature search strategies and to Dr. Kelly Hallman for her input on framing article content.

\section{Authors' contributions}

ICT designed the systematic review, searched and screened articles, extracted data, and wrote the manuscript. HTF searched and screened articles, extracted data, and critically reviewed the manuscript. HM and SM critically reviewed the manuscript. The authors read and approved the final manuscript.

\section{Funding}

This manuscript is not funded by any grantor or funding body.

\section{Availability of data and materials}

The peer-reviewed and grey literature analyzed in this systematic review is publicly available online. Grey literature is available on the Humanitarian Response website, Save the Children Sweden - Resource Centre, the CP AoR website, IOM Online bookstore, and UNHCR's online need assessments (https://www.humanitarianresponse.info/; https://resourcecentre. savethechildren.net; http://cpwg.net/resource-topics/assessment-3/; http:// cpwg.net/starter-packs/; http://publications.iom.int/; http://needsassessment. unhcr.org/tools-and-templates/). All other remaining grey literature reports are available upon request from the lead agency or the CP AoR. Further requests for data may be directed to the corresponding author at it2208@caa. columbia.edu.

\section{Declarations}

Ethics approval and consent to participate

This systematic review is based upon deidentified secondary literature that is available in the public domain.

\section{Consent for publication}

Not applicable.

\section{Competing interests}

The authors declare that they have no competing interests.

\section{Author details}

${ }^{1}$ Global Health and Development, London School of Hygiene and Tropical Medicine, London, UK. ${ }^{2}$ Mailman School of Public Health, Columbia University, New York, USA.

Received: 2 November 2020 Accepted: 9 June 2021

Published online: 12 July 2021

References

1. Webster PJ, Holland GJ, Curry JA, Chang HR. Changes in tropical cyclone number, duration, and intensity in a warming environment. Science. 2005 309(5742):1844-6. https://doi.org/10.1126/science.1116448.

2. Centre for Research on the Epidemiology of Disasters. Natural disasters 2017: Centre for Research on the Epidemiology of Disasters; 2018. https:// cred.be/sites/default/files/adsr_2017.pdf. Accessed 21 Apr 2021

3. United Nations Children's Fund. Annual Report 2017: United Nations Children's Fund; 2018. www.unicef.org/publications. Accessed 27 Jan 2019

4. International Displacement Monitoring Centre. Global report on internal displacement - GRID 2017. Int Displace Monit Centre. 2017; http://www. internal-displacement.org/global-report/grid2017/pdfs/2017-GRID.pdf. Accessed 4 Apr 2018.

5. Brown O. The numbers game. Forced Migr Rev. 2008;31:8-9.

6. International Displacement Monitoring Centre. Global report on internal displacement - GRID 2018. Int Displace Monit Centre. 2018; http://www. internal-displacement.org/global-report/grid2018/downloads/2018-GRID.pdf. Accessed 10 June 2019.

7. Al Gasseer N, Dresden E, Keeney G, Warren N. Status of women and infants in complex humanitarian emergencies. J Midwifery Womens Health. 2004; 49(4 Suppl 1):7-13. https://doi.org/10.1016/j.jmwh.2004.05.001.

8. Hori M, Schafer MJ, Bowman DJ. Displacement dynamics in southern Louisiana after hurricanes Katrina and Rita. Popul Res Policy Rev. 2009;28(1): 45-65. https://doi.org/10.1007/s11113-008-9118-1.

9. Neria Y, Nandi A, Galea S. Post-traumatic stress disorder following disasters: a systematic review. Psychol Med. 2008:38(4):467-80. https://doi.org/10.101 7/S0033291707001353.

10. Norris FH, Friedman MJ, Watson PJ, Byrne CM, Diaz E, Kaniasty K. 60,000 disaster victims speak: part I. an empirical review of the empirical literature, 1981-2001. Psychiatry. 2002;65(3):207-39. https://doi.org/10.1521/psyc.65.3.2 07.20173.

11. Kirsch TD, Mitrani-Reiser J, Bissell R, Sauer LM, Mahoney M, Holmes WT, et al. Impact on hospital functions following the 2010 Chilean earthquake. Disaster Med Public Health Prep. 2010;4(2):122-8. https://doi.org/10.1001/ dmphp.4.2.122.

12. Schuller M. Hitting home: humanitarian impacts on Haiti's households. In: Humanitarian aftershocks in Haiti. New Brunswick: Rutgers University Press; 2016. p. 75-100. https://doi.org/10.36019/9780813574264.

13. Cas AG, Frankenberg E, Suriastini W, Thomas D. The impact of parental death on child well-being: evidence from the Indian Ocean tsunami. Demography. 2014;51(2):437-57. https://doi.org/10.1007/s13524-014-0279-8.

14. Stark L, MacFarlane M, Rubenstein BL, Yu G, Jensen C, Williamson K. Using a population-based survey approach to estimate child separation after a natural disaster: findings from post-hurricane Haiti. BMJ Glob Health. 2018; 3(3):e000784. https://doi.org/10.1136/bmjgh-2018-000784. 
15. Biswas A, Rahman A, Mashreky S, Rahman F, Dalal K. Unintentional injuries and parental violence against children during flood: a study in rural Bangladesh. Rural Remote Health. 2010;10(1):1199.

16. Project S. Sphere handbook: humanitarian charter and minimum standards in disaster response. 3rd ed. Rugby: Practical Action Publishing; 2011. https://doi.org/10.3362/9781908176202.

17. Stark L, Landis D. Violence against children in humanitarian settings: a literature review of population-based approaches. Soc Sci Med. 2016;152: 125-37. https://doi.org/10.1016/j.socscimed.2016.01.052.

18. Rubenstein BL, Lu LZN, MacFarlane M, Stark L. Predictors of interpersonal violence in the household in humanitarian settings: a systematic review. Trauma Violence Abuse. 2017;21:1-14.

19. Alliance for Child Protection in Humanitarian Action. Minimum standards for child protection in humanitarian action: Alliance for Child Protection in Humanitarian Action; 2019. https://alliancecpha.org/en/CPMS_home. Accessed 25 Sept 2020

20. Catani C, Jacob N, Schauer E, Kohila M, Neuner F. Family violence, war, and natural disasters: a study of the effect of extreme stress on children's mental health in Sri Lanka. BMC Psychiatry. 2008;8(1):33. https://doi.org/10.1186/14 71-244X-8-33.

21. Fletcher SM, Thiessen J, Gero A, Rumsey M, Kuruppu N, Willetts J. Traditional coping strategies and disaster response: examples from the South Pacific region. J Environ Public Health. 2013;1:264503.

22. De Juan A, Pierskalla JH. Civil war violence and political trust: microlevel evidence from Nepal. Confl Manag Peace Sci. 2016;33(1):67-88. https://doi. org/10.1177/0738894214544612.

23. Rohner D, Thoenig M, Zilibotti F. Seeds of distrust: conflict in Uganda. J Econ Growth. 2013;18(3):217-52. https://doi.org/10.1007/s10887-013-9093-1.

24. Pujadas Botey A, Kulig JC. Family functioning following wildfires: recovering from the 2011 slave Lake fires. J Child Fam Stud. 2013;23:1471-83.

25. Lindgaard CV, Iglebaek T, Jensen TK. Changes in family functioning in the aftermath of a natural disaster: the 2004 tsunami in Southeast Asia. J Loss Trauma. 2009;14(2):101-16. https://doi.org/10.1080/15325020802537138.

26. Daimon H, Atsumi T. Simulating disaster volunteerism in Japan: "pay it forward" as a strategy for extending the post-disaster altruistic community. Nat Hazards. 2018;93(2):699-713. https://doi.org/10.1007/s11069-018-3309-9.

27. Laycock KE, Caldwell W. Exploring community cohesion in rural Canada post-extreme weather: planning ahead for unknown stresses. Soc Indic Res. 2018;139(1):77-97. https://doi.org/10.1007/s11205-017-1706-1.

28. Calo-Blanco A, Kovárík J, Mengel F, Romero JG. Natural disasters and indicators of social cohesion. PLoS One. 2017;12(6):e0176885. https://doi. org/10.1371/journal.pone.0176885.

29. Siegrist M, Sütterlin B. Human and nature-caused hazards: the affect heuristic causes biased decisions. Risk Anal. 2014;34(8):1482-94. https://doi. org/10.1111/risa.12179.

30. Rodriguez CM, Green AJ. Parenting stress and anger expression as predictors of child abuse potential. Child Abus Negl. 1997;21(4):367-77. https://doi.org/10.1016/S0145-2134(96)00177-9.

31. Egami Y, Ford DE, Greenfield SF, Crum RM. Psychiatric profile and sociodemographic characteristics of adults who report physically abusing or neglecting children. Am J Psychiatry. 1996;153(7):921-8. https://doi.org/10.11 76/ajp.153.7.921

32. Schaeffer CM, Alexander PC, Bethke K, Kretz LS. Predictors of child abuse potential among military parents: comparing mothers and fathers. J Fam Violence. 2005;20(2):123-9. https://doi.org/10.1007/s10896-005-3175-6.

33. Brown J, Cohen P, Johnson JG, Salzinger S. A longitudinal analysis of risk factors for child maltreatment: findings of a 17-year prospective study of officially recorded and self-reported child abuse and neglect. Child Abuse Negl. 1998;22(11):1065-78. https://doi.org/10.1016/S0145-2134(98)00087-8.

34. Cerna-Turoff I, Fang Z, Meierkord A, Wu Z, Yanguela J, Bangirana CA, et al. Factors associated with violence against children in low- and middleincome countries: a systematic review and meta-regression of nationally representative data. Trauma Violence Abuse. 2021;22(2):219-32. https://doi org/10.1177/1524838020985532.

35. Cerna-Turoff I, Fischer H-T, Mayhew S, Devries K. Violence against children and natural disasters: a systematic review and meta analysis of quantitative evidence. PLoS One. 2019;14(5):e0217719. https://doi.org/10.1371/journal. pone.0217719.

36. Moher D, Liberati A, Tetzlaff J, Altman DG, The PRISMA Group. Preferred reporting items for systematic reviews and meta-analyses: the PRISMA statement. PLoS Med. 2009;6(6):e1000097.
37. United Nations Children's Fund. Hidden in plain sight: a statistical analysis of violence against children: United Nations Children's Fund; 2014. https:// www.unicef.org/publications/index_74865.html. Accessed 25 Sept 2020

38. Centre for Research on the Epidemiology of Disasters, United Nations Office for Disaster Risk Reduction. Economic losses, poverty and disasters, 19982017: Centre for Research on the Epidemiology of Disasters; 2018. https:// www.cred.be/sites/default/files/CRED_Economic_Losses_10oct.pdf. Accessed 21 Apr 2021

39. Perrow C. Next catastrophe: reducing our vulnerabilities to natural, industrial, and terrorist disasters. Princeton: Princeton University Press; 2011. https://doi.org/10.1515/9781400838516.

40. Boluyt N, Tjosvold L, Lefebvre C, Klassen TP, Offringa M. Usefulness of systematic review search strategies in finding child health systematic reviews in MEDLINE. Arch Pediatr Adolesc Med. 2008;162(2):111-6. https:// doi.org/10.1001/archpediatrics.2007.40.

41. Meinck F, Cluver LD, Boyes ME, Mhlongo EL. Risk and protective factors for physical and sexual abuse of children and adolescents in Africa: a review and implications for practice. Trauma Violence Abuse. 2015;16(1):81-107. https://doi.org/10.1177/1524838014523336.

42. Centre for Research on the Epidemiology of Disasters. General classification. Centre for Research on the Epidemiology of Disasters. 2009. https://www. emdat.be/classification. Accessed 17 Sept 2019.

43. Godin K, Stapleton J, Kirkpatrick SI, Hanning RM, Leatherdale ST. Applying systematic review search methods to the grey literature: a case study examining guidelines for school-based breakfast programs in Canada. Syst Rev. 2015;4(1):138. https://doi.org/10.1186/s13643-015-0125-0.

44. Braun V, Clarke V, Hayfield N, Terry G. Thematic analysis. In: Liamputtong P, editor. Handbook of research methods in health social sciences. Singapore: Springer Singapore; 2019. p. 843-60. https://doi.org/10.1007/978-981-10-52 51-4_103.

45. Glaser BG. The constant comparative method of qualitative analysis. Soc Probl. 1965;12(4):436-45. https://doi.org/10.2307/798843.

46. Dixon-Woods M, Sutton A, Shaw R, Miller T, Smith J, Young B, et al. Appraising qualitative research for inclusion in systematic review: a quantitative and qualitative comparison of three methods. J Health Serv Res Policy. 2007;12(1):42-7. https://doi.org/10.1258/135581907779497486.

47. National Institute of Health - National Heart Lung and Blood Institute. Study quality assessment tools: National Institute of Health; 2014. https://www.nhlbi. nih.gov/health-topics/study-quality-assessment-tools. Accessed 3 June 2018

48. Higgins J, Green S. Cochrane handbook for systematic reviews of interventions. 5.1.0. West Sussex: The Cochrane Collaboration \& John Wiley \& Sons, Ltd.; 2011.

49. Rashid SF, Michaud S. Female adolescents and their sexuality: notions of honour, shame, purity and pollution during the floods. Disasters. 2000;24(1): 54-70. https://doi.org/10.1111/1467-7717.00131.

50. Curtis T, Miller BC, Berry EH. Changes in reports and incidence of child abuse following natural disasters. Child Abuse Negl. 2000;24(9):1151-62. https://doi.org/10.1016/S0145-2134(00)00176-9.

51. Terranova AM, Boxer P, Morris AS. Changes in children's peer interactions following a natural disaster: how predisaster bullying and victimization rates changed following hurricane Katrina. Psychol Sch. 2009;46(4):333-47. https://doi.org/10.1002/pits.20379.

52. Scott BG, Lapré GE, Marsee MA, Weems CF. Aggressive behavior and its associations with posttraumatic stress and academic achievement following a natural disaster. J Clin Child Adolesc Psychol. 2014;43(1):43-50. https://doi. org/10.1080/15374416.2013.807733

53. Davis L, Bookey B. Fanm ayisyen pap kase: respecting the right to health of Haitian women and girls. Health Hum Rights. 2011;13(1):E50-61.

54. Standing K, Parker S, Bista S. Grassroots responses to violence against women and girls in post-earthquake Nepal: lessons from the field. Gend Dev. 2016;24(2):187-204. https://doi.org/10.1080/13552074.2016.1194562.

55. Fisher $\mathrm{S}$. Violence against women and natural disasters: findings from posttsunami Sri Lanka. Violence Against Women. 2010;16(8):902-18. https://doi. org/10.1177/1077801210377649.

56. Child Protection Sub-Cluster. Protection risks for children as a result of Typhoon Bopha (Pablo): inter-agency child protection rapid assessment report: Child Protection Sub-Cluster; 2013. https://reliefweb.int/sites/ reliefweb.int/files/resources/Child\%20Protection\%20Rapid\%20Assessment\%2 OReport\%20PHL-final\%20Sept\%202013.pdf. Accessed 21 Apr 2021

57. International Federation of Red Cross and Red Crescent Societies. The responsibility to prevent and respond to sexual and gender-based violence 
in disasters and crises. In: Research results of sexual and gender-based violence (SGBV) prevention and response before, during and after disasters in Indonesia, Lao PDR and the Philippines: International Federation of Red Cross and Red Crescent Societies; 2018. https://media.ifrc.org/ifrc/wpcontent/uploads/sites/5/2018/07/17072018-SGBV-Report_Final.pdf.pdf. Accessed 25 Sept 2020.

58. Jinks B, Komengi J. Kandep Basin, Enga Province and Panduaga Valley, Hela Province PNG food security impact assessment 2015-2016 (CPP). 2016. https:// www.humanitarianresponse.info/en/operations/papua-new-guinea/document/ food-security-assessment-report-kandep-panduaga. Accessed 25 Sept 2020

59. Polack E. Child rights and climate change adaptation: voices from Cambodia and Kenya. In: Children in a Changing Climate; 2010. https:// resourcecentre.savethechildren.net/library/child-rights-and-climate-change-a daptation-voices-kenya-and-cambodia. Accessed 25 Sept 2020.

60. United Nations Population Fund, Ministère à la Condition féminine et aux Droits des femmes. Gender based violence rapid assessment report: GBV Sub-Sector Hurricane Mathew humanitarian response: United Nations Population Fund; 2016. https://www.humanitarianresponse.info/sites/www. humanitarianresponse.info/files/assessments/gbv_rapid_assessment_subsector_report_final.pdf. Accessed 25 Sept 2020

61. Ministry of International Affairs of the Government of the Kingdom of Tonga, Pacific Humanitarian Cluster. Safety and protection assessment: TC lan - Ha'apai, Tonga: Ministry of International Affairs of the Government of the Kingdom of Tonga; 2014. https://reliefweb.int/sites/reliefweb.int/files/ resources/TongaSafety and Protection Assessment Report post TC lan.pdf. Accessed 25 Sept 2020

62. People in Need Czech Republic. Her safety assessment report. People in Need Czech Republic. 2015. https://www.humanitarianresponse.info/sites/ www.humanitarianresponse.info/files/assessments/her_safety_assessment_ final.pdf. Accessed 25 Sept 2020.

63. People in Need Czech Republic. Assessment of girls attending school in Sindhupalchok. People in Need Czech Republic. 2015. https://www.huma nitarianresponse.info/en/operations/nepal/document/sindhupalchwokgirls-assessmentfinal. Accessed 25 Sept 2020.

64. Plan International, Save the Children, United Nations Children's Fund, World Vision. After the earthquake: Nepal's children speak out - Nepal children's earthquake recovery consultation: Plan International; 2015. https://www.alna p.org/help-library/after-the-earthquake-nepals-children-speak-out-nepalchildrens-earthquake-recovery. Accessed 25 Sept 2020

65. Save the Children. Rapid needs assessment report (ver. 2) Mongolian dzud 2016-2017: Save the Children; 2017. https://resourcecentre.savethechildren. net/library/rapid-needs-assessment-report-ver2-mongolian-dzu-2016-2017. Accessed 25 Sept 2020

66. Save the Children. Effects of drought in East Sepik, PNG: assessment report: Save the Children; 2015. https://reliefweb.int/report/papua-new-guinea/ effects-drought-east-sepik-png-assessment-report. Accessed 25 Sept 2020

67. Government of Bangladesh, Humanitarian Coordination Task Team of Bangladesh. Floods in northeast (Haor) areas of Bangladesh, April-May 2017: Government of Bangladesh; 2017. https://www.humanitarianresponse.info/ en/operations/bangladesh/document/bangladesh-floods-northeast-haor-a reas-april-may-2017. Accessed 25 Sept 2020

68. Save the Children. Rapid child protection assessment Wajir: Save the Children; 2011. http://www.cpaor.unicefintercluster.net/sites/default/files/cp/ Kenya-CPRAT-SC-2011-ENG.doc. Accessed 23 Apr 2021

69. Oxfam, CARE Ethiopia. Consolidated gender analysis for the Ethiopian drought response: Oxfam; 2016. https://www.humanitarianresponse.info/en/ operations/ethiopia/document/cp-situationalcontextual-monitoring-indica tors. Accessed 25 Sept 2020.

70. Civil Protection Zimbabwe. Inter-agency flooding rapid assessment report, Tsholotsho district, 23-24 February - 2017: Civil Protection Zimbabwe; 2017. https://www.humanitarianresponse.info/en/operations/zimbabwe/ document/zimbabwe-inter-agency-flooding-rapid-assessment-reporttsholotsho. Accessed 25 Sept 2020

71. CARE Ethiopia Emergency Unit. Rapid gender analysis: research report: Care Ethiopia; 2016. https://www.care-international.org/files/files/170616_Rapid_ Gender_Analysis_Report.pdf. Accessed 25 Sept 2020

72. Save the Children. Child protection needs assessment. Somalia: Save the Children; 2017. https://doi.org/10.7910/DVN/NVNMEH. Accessed 25 Apr 2021

73. Uppsala University - Department of Peace and Conflict Research. Uppsala conflict data program. Uppsala; 2020. https://ucdp.uu.se/. Accessed 10 Aug 2020
74. Angrist JD, Imbens GW, Rubin DB. Identification of causal effects using instrumental variables. J Am Stat Assoc. 1996;91(434):444-55. https://doi. org/10.1080/01621459.1996.10476902.

75. Rhodes J, Chan C, Paxson C, Rouse CE, Waters M, Fussell E. The impact of hurricane Katrina on the mental and physical health of low-income parents in New Orleans. Am J Orthop. 2010;80(2):237-47.

76. Galea S, Brewin CR, Gruber M, Jones RT, King DW, King LA, et al. Exposure to hurricane-related stressors and mental illness after hurricane Katrina. Arch Gen Psychiatry. 2007;64(12):1427-34. https://doi.org/10.1001/archpsyc. 64.12.1427.

77. United Nations High Commissioner on Refugees - Division of International Protection. Action against sexual and gender-based violence: an updated strategy: United Nations High Commissioner on Refugees; 2011. http:// www.refworld.org/pdfid/4e01ffeb2.pdf. Accessed 9 Oct 2018

78. Raising Voices. SASA! Mobilizing communities to inspire social change: Raising Voices; n.d. https://raisingvoices.org/wp-content/uploads/2013/03/ downloads/resources/Unpacking_Sasa!.pdf. Accessed 16 Apr 2021

79. Sim A, Puffer E, Green E, Chase R, Zayzay J, Garcia-Rolland E, et al. Parents make the difference: findings from a randomized impact evaluation of a parenting program in rural Liberia: International Rescue Committee; 2014. https://www.rescue.org/sites/default/files/document/704/parentsma kedifferencereportfinal18nov14.pdf. Acccessed 16 Apr 2021

80. Cure Violence. Essential elements. Chicago: Cure Violence; 2020. https:// cureviolence.org/the-model/essential-elements/. Acccessed 16 Apr 2021

81. World Health Organization. INSPIRE: seven strategies for ending violence against children: World Health Organization; 2016. https://www.who.int/ publications/i/item/inspire-seven-strategies-for-ending-violence-againstchildren. Acccessed 16 Apr 2021

82. Hillis S, Mercy J, Amobi A, Kress H. Global prevalence of past-year violence against children: a systematic review and minimum estimates. Pediatrics. 2016;137(3):e20154079. https://doi.org/10.1542/peds.2015-4079.

83. Robins JM, Greenland S. Identifiability and exchangeability for direct and indirect effects. Source Epidemiol. 1992;3(2):143-55. https://doi.org/10.1097/ 00001648-199203000-00013.

84. Crea TM, Reynolds AD, Bunkers KMC, Bishop CM. Social service systems for vulnerable children and families in low- and middle-income countries: establishing definitions and key components. Int J Soc Welf. 2018;27(3):30515. https://doi.org/10.1111/ijsw.12306.

85. Stoltenborgh M, van IJzendoorn MH, Euser EM, Bakermans-Kranenburg MJ. A global perspective on child sexual abuse: meta-analysis of prevalence around the world. Child Maltreat. 2011;16(2):79-101. https://doi.org/10.11 77/1077559511403920.

86. Kaniasty K, Norris FH. In search of altruistic community: patterns of social support mobilization following hurricane Hugo. Am J Community Psychol. 1995;23(4):447-77. https://doi.org/10.1007/BF02506964.

87. Howell J, Elliott JR. Damages done: the longitudinal impacts of natural hazards on wealth inequality in the United States. Soc Probl. 2019;66(3): 448-67. https://doi.org/10.1093/socpro/spy016.

88. Massey DS. American apartheid: segregation and the making of the underclass. Am J Sociol. 1990;96(2):329-57. https://doi.org/10.1086/229532.

89. Saporito S, Sohoni D. Mapping educational inequality: concentrations of poverty among poor and minority students in public schools. Soc Forces. 2007;85(3):1227-53. https://doi.org/10.1353/sof.2007.0055.

90. High-Level Panel on Humanitarian Financing. Too important to fail addressing the humanitarian financing gap: High-Level Panel on Humanitarian Financing; 2016. https://reliefweb.int/sites/reliefweb.int/files/ resources/\%5BHLP Report\%5D Too important to fail-addressing the humanitarian financing gap.pdf. Accessed 1 Dec 2019

\section{Publisher's Note}

Springer Nature remains neutral with regard to jurisdictional claims in published maps and institutional affiliations. 